\title{
Electoral Competition in Connecticut's State House Races: The Trial Run of the Citizens' Election Program
}

\author{
Lesley DeNardis ${ }^{1}$ \\ ${ }^{1}$ Department of Government and Politics, Sacred Heart University, Fairfield, Connecticut, USA \\ Correspondence: Lesley DeNardis, Department of Government and Politics, Sacred Heart University, Fairfield, \\ Connecticut, USA. Tel: 1-203-371-7834. E-mail: denardisl@sacredheart.edu
}

Received: March 23, 2013 Accepted: April 23, 2013 Online Published: October 11, 2013

doi:10.5539/par.v2n2p210 URL: http://dx.doi.org/10.5539/par.v2n2p210

\begin{abstract}
The Citizens Election Fund, Connecticut's version of a clean elections law, was established in 2005 in the wake of the corruption scandal during the administration of Governor John Rowland. Modeled after the public financing systems of Maine and Arizona, Connecticut's law has been touted as the most comprehensive in the nation. Scholars have hypothesized that states with public funding of campaigns have more competitive elections (Werner \& Mayer, 2007). This paper will address whether the introduction of the Citizens' Election Program has increased the level of electoral competition by specifically focusing on state house seats in Connecticut during the 2008 and 2010 election cycles. Contestation for seats in the Connecticut General Assembly is a particularly salient issue due to the fact that many seats typically go unchallenged and as Mayer (2007) observed "a seat in the Connecticut House or Senate had become one of the safest offices anywhere, approaching if not exceeding the security of membership in the U.S. Congress." The findings suggest that the hypothesized positive relationship between public financing and electoral competition show mixed results. After the introduction of the Citizens' Election Program, the number of uncontested seats decreased slightly with more challengers emerging to contest incumbents in the 2008 and 2010 election cycles. While some positive effects are seen by the 2010 election cycle with the margin of votes cast for winners narrowing in $41 \%$ of house races, the vast majority of house incumbents continue to win and do so by larger vote margins. Finally, the overall reelection rate for incumbents remained largely unchanged. Further research with a longer time horizon that is inclusive of more state house elections will have to be conducted before any firmer conclusions can be drawn regarding the efficacy of the Citizens' Election Program.
\end{abstract}

Keywords: Citizens' Election Program, public financing, election campaigns, state government, electoral competition

\section{Introduction}

\section{1}

The year 2004 was a tumultuous one in Connecticut state government. Revelations of graft and corruption led to the resignation of Governor John Rowland. In the wake of the scandal, the Connecticut General Assembly adopted the most comprehensive public election finance system in the country. While Maine and Arizona's clean election laws predated that of Connecticut's by several years, Connecticut's program was the most sweeping in terms of its scope. Unlike its counterparts in other states whose clean election laws provided partial funding for select public offices, Connecticut's law established full financing for all state offices (Nyart, 2006). In addition, Connecticut was also the only state to adopt the law via the legislative process whereas Maine and Arizona had enacted their programs through a ballot initiative. Sensing the public outrage and appetite for reform, state legislators prepared to tackle the issue directly.

The moniker "clean elections" has been applied to public funding of campaigns since its inception in Arizona in 2000. (Note 1) Among the ascribed benefits of public funding for election campaigns are: lowering the barriers to entry for emergent candidates, broadening the pool of candidates in terms of ideological and geographic diversity, reducing the incumbency advantage, and controlling campaign costs (Mayer, Werner, \& Williams, 2005). Relative newcomers to the political process who would ordinarily have a difficult time raising funds and might otherwise be discouraged from running would now have the necessary financial support to mount a viable campaign against an incumbent. Critics, on the other hand, deride public financing as little more than an incumbent protection act 
arguing that it does little more than to solidify the advantage of incumbents and effectively handicap challengers who must abide by set spending levels (Fahle, 2009).

\section{2}

Clean elections laws have been heralded by proponents as a panacea for a variety of ills including government corruption and lethargic electoral competition. The major assumption underlying the removal of private money in campaigns is that it would lessen corruption. Legislators would no longer be beholden to the special interest groups that once funded their election campaigns. Additional theorized benefits include the impact on electoral competition. Challengers, traditionally at a disadvantage to incumbents due to the fundraising factor, would be induced to run for office. The removal of special interest money as well as the emergence of newcomers to public office are both viewed as positive outcomes for electoral democracy. Since the advent of public financing for campaigns in Minnesota in the early 1990s, more than twenty states have adopted some version of a clean elections law (Brickner, 2008).

Despite the initial enthusiasm for clean election laws among reformers, some scholars are less sanguine about the purported benefits of clean elections. For instance, Mayer, Werner and Williams (2005) assert that much of the fanfare surrounding public funding programs is unwarranted by arguing that reforms have largely been adopted in the absence of studies that document their efficacy. In fact, until recently: "the elements of clean elections, funding amounts, eligibility rules, and spending limits are based more on guesswork than solid evidence." $(2005$, p. 3$)$

\section{3}

With an increasing number of states adopting clean elections laws since then, scholars have filled the empirical void that has largely preceded policy adoption in earlier years and have conducted studies which measure the effects of public financing programs. In a multi-state study that included Maine, Arizona, Minnesota, Hawaii and Wisconsin spanning the years from 1998-2004, Mayer, Werner and Williams (2005) found that public funding induced challengers to emerge and increased the pool of candidates thereby increasing the chances for competitive races in all states but Hawaii and Wisconsin. They also found that the reelection rates for incumbents in Maine and Arizona decreased. However, they were cautious about attributing this to public funding. (p. 20). As an important caveat to their results, Hawaii and Wisconsin were found not to have experienced positive effects from their clean election programs. The grants comprised only a small fraction of the candidates' total funds which included private sources of funding and thus did not have an appreciable impact on electoral outcomes. Similarly, Mayer and Wood (1995) that public funding had no appreciable impact on electoral competition in Wisconsin from 1964-1990.

Another important finding which emerged from Mayer et al's (2005) study is that the design of public financing programs does matter. Grant amounts that are either too generous or too stingy may inhibit candidate emergence and competitiveness. $(2005$, p. 22) The sensitivity of election results to program design was also noted by Donnay and Ramsden (1995) who observed "that public funding can considerably help a challenger's campaign but it must be tempered with the knowledge that public financing also helps incumbents" (p. 362). Hence, their study included a dichotomous variable to measure whether the incumbent and challenger both accept public funds and how this would impact their respective vote shares. Put differently, the design of public finance systems such as grant size creates incentives or disincentives that political actors respond to in deciding whether to accept public funding. Finally, drawing parallels between Maine and Arizona in order to speculate about the impact of clean elections in Connecticut, Mayer anticipated that elections will become more competitive in Connecticut due to the Citizens' Election Program and what many viewed as a particularly generous grant amount relative to other states. Noting the unusually uncompetitive environment, Mayer (2007) predicted that "the generous grant levels will give challengers, in particular, access to an unprecedented level of resources. We find it difficult not to believe that doubling the average amount of challenger spending will have a major effect on competition." (p. 23)

These studies shed considerable light on the design and implementation of clean election laws in other states. To the knowledge of this author, no statistical studies have been conducted which measure the impact of Connecticut's Citizens' Election Program on electoral competition. This study seeks to fill this void with an analysis of Connecticut's house races in the 2008 and 2010 election cycles. While the program was touted in a program evaluation as a "A Novel System with Extraordinary Results" (SEEC, 2011) by the agency charged with the task of implementing the program, this study aims to determine whether such a view is warranted. In the section that follows, a brief overview of the legislative history surrounding the passage of the clean elections law in Connecticut will be followed by data and findings from the 2006, 2008 and 2010 election cycles to test the hypothesized relationship between public funding and electoral competition. 


\section{The political landscape in Connecticut pre-CEP: A "sclerotic" (Note 2) electoral system}

Rowland's corruption scandal and subsequent resignation from office in 2004 hastened the passage of the Act Concerning Comprehensive Reform for Statewide Constitutional and General Assembly Offices. Reformers such as Common Cause had spent a decade attempting to move the issue onto the legislative agenda to no avail (Nyart, 2006). The Rowland corruption scandal was the catalyst that propelled the issue of campaign finance reform to the forefront of the policy agenda.

The primary goal of the program is to eliminate the influence of special interest money in Connecticut politics. A secondary goal of the program seeks to increase electoral competition, which is a particularly salient issue given the political landscape in Connecticut. The incumbency advantage, reinforced by legislative districting, has gradually accrued to Democrats. Lockard (1959) observed that until 1959, there was close party competition in Connecticut with Republicans holding the advantage in terms of seats in the General Assembly. In fact, for much of the $20^{\text {th }}$ century, until the apportionment revolution in the 1960's and 1970s, the State House in Connecticut had been dominated by Republicans (Lockard, 1959). With the greater weight that reapportionment gave the traditionally-Democratic urban centers, the Connecticut state house has been under Democratic control for all but two of the last thirty five years. As Rose observed (2007), "From 1987 to 2005, the Democrats on average have occupied 62 percent of the seats, a most comfortable margin of power." (p. 60). The Connecticut scenario, while more pronounced than other states, is illustrative of larger national trends which saw the routine reelection of incumbents. In fact, $95 \%$ of incumbents in state houses across the country have been reelected since 1996 (Mayer $\&$ Werner, 2008). Mayer also found that in tandem with the incumbency advantage and perhaps reinforcing it is the increase in the number of uncontested seats. In contrast to the 1970s when almost every seat in the Connecticut General Assembly was challenged, by 2006 that number had shrunk to $58 \%$ of House incumbents who faced an opponent $(2007,14)$. Rose $(2007)$ noted that:

In the 2004 state legislative elections, 82 percent of seats in the state house of representatives were either uncontested by one of the major political parties, or won by a margin of 10 or more percentage points. Of those house seats in either the uncontested or "safe" category, 68 percent were held by Democrats. (p. 61).

Moreover, incumbents who did face challengers during this time period were not in competitive contests, defined as those in which the incumbent receiving less than $60 \%$ of the vote.

As Mayer (2007) observed:

Our chief finding is that the electoral environment in Connecticut has changed in the last decade, moving from a period of sustained competition that had lasted since the 1930s, to one of the least competitive electoral systems in the country. Beginning in the late 1980s, legislative elections became increasingly one-sided affairs. By 2000, a seat in the Connecticut House or Senate had become one the safest offices anywhere, approaching if not exceeding the security of membership in the U.S. Congress. We are unable to tie this development to any single causal factor, but likely culprits include the increasing professionalization of the legislature, the creation of safe districts through redistricting, and challengers' inability to raise sufficient funds. (p. 3)

Legislative professionalization may also contribute to the incumbency advantage as incumbents view the trappings of office as being increasingly more attractive thus making retaining their seats becomes more important. All of these three factors have converged to create an uncompetitive political system.

\section{Timing is Everything}

Passage of the Citizens' Election Program occurred after a lengthy debate in the House and Senate. On November 30, 2005, a special session was called to deliberate Emergency Certification Senate Bill 2103. The public financing of elections provision of the bill was part of an omnibus package of legislation that contained various provisions including a ban on contributions from lobbyists and state contractors. Upon introducing the bill, Representative Caruso $\left(126^{\text {th }}\right.$ district), the chief architect of the bill, spoke of the fifteen years to bring the issue of campaign finance reform to the agenda by commenting that the "stars are aligned with this legislation" (p. 8). The issue was ripe for consideration and as Nyart (2006) observed "the combination of a corruption-ridden political environment and pressure from the grassroots had created a situation in which the Governor and Democratic legislative leaders all wanted to be seen as strong advocates for reform" $(2006,5)$. When Governor Jodi Rell took office in 2005, she made campaign finance reform the centerpiece of her administration. Cognizant of the fact that Republicans had typically not favored reform, she convened a group of Democrats to begin work on crafting a bill to which various objections were made by Republican legislators during deliberations. Republican lawmakers lodged major objections ranging from the procedural to the substantive. From a procedural perspective, they derided the measure 
for being passed without their input. Some recounted the rapidity with which the bill was moved through the legislature with only twenty four hours to review the bill. Apart from the procedural objections, some legislators addressed the substance of the bill which in their view did not fully address the issue of special interest money. A major source of disagreement was the provision that replaced special interest PACs with political action committees controlled by legislative leaders or political caucuses (Representative Ward, Final Senate Debate, November 30, 2005, p. 13). By allowing such PACs to spend money on behalf of house and senate races of their choosing, critics derided this as a major loophole in the legislation. Representative Miner $\left(66^{\text {th }}\right.$ district $)$ offered the following regarding the major shortcomings of the legislation:

I heard the Chairman say that the stars are aligned, and I think he's right. I think the stars are aligned. I think people are going to grasp at this Bill and they're going to support this because the public believes that something good is going to come out of it. And that whatever corruption may have existed in the past is going to mysteriously go away. Right now people have to disclose where the money comes from. Everybody that writes a check to you or me has to disclose who they are, what they're giving, where they live. What this is going to do is it's going to force money into other areas and it's going to come back in in-kind services that I don't think anybody is going to track. I don't know if anybody is going to know whether the individual hired by the minority leader's PAC is working for you or me or anybody else. (p. 66)

Another major stumbling block to the bill raised by Republicans was the use of taxpayers' money to fund election campaigns. Still others questioned the inherent constitutionality of efforts to regulate campaign contributions as infringing on free speech. With respect to the first objection, proponents of the bill argued that the financing of election campaigns through taxes was superior to the system of continuing to allow special interests to contribute to campaigns. The removal of special interest money from campaigns was to have a sanitizing effect that would not only free up candidates' time from having to raise money but afford them greater independence once in office and not be beholden to the special interests that helped get them elected. Opponents of the bill pointed out that while PACs could no longer contribute to campaigns, there were still loopholes in the law that would enable these groups to circumvent the law.

Finally, fiscal conservatives found the use of taxpayers' money to fund campaigns objectionable. The Citizens' Election Fund would require roughly twenty million dollars a year to operate and would be financed largely through escheats or unclaimed property. It would also create a new agency, the Citizens' Election Enforcement Commission, to administer the program. Despite the objections, the bill passed along largely partisan lines with a vote of 27-8 in the Senate and 82-65 in the House. Public Act 05-5 officially established the Citizens' Election Program whose goals are five-fold: 1) increase voter choice, 2) increase electoral competition, 3) increase voter participation, 4) reduce special interest group influence, and 5) curb campaign cost increases. This paper will focus on the second goal of increasing electoral competition. The program, as set forth in chapter 157 of the Connecticut General Statutes, provides voluntary, public financing to qualified candidates including all statewide offices as well as the General Assembly. To qualify, state house candidates must meet two thresholds: raise $\$ 5,000$ through small individual donations ranging from \$5-100 and obtain 150 signatures of residents in their districts (CEP, 2009). In return for foregoing private funding, state house candidates who participate in the Citizens' Election Program receive a $\$ 25,000$ grant. In addition the five thousand dollars which they have raised to qualify for the grant, candidates must abide by this spending limit and agree to use their funds only on permissible campaign expenditures as regulated by the CEP.

Since 2005, Connecticut's clean election law joins the ranks of other states that have similar programs notably Arizona and Maine, whose program design most closely resembles that of Connecticut. The citizens of Maine and Arizona passed clean election laws by ballot initiatives in 1996 and 1998, respectively. Participating candidates in Arizona must raise $\$ 5$ contributions from 220 citizens from their district. Upon reaching this threshold they qualify for a $\$ 21,479$ grant. (CCEC, 2010). Given the similarity of Connecticut's clean election law with those of Arizona and Maine, campaign finance scholars Mayer and Williams (2008) expect that we should see a similarly salutary effect on electoral competition. The data and methods section below discuss the finding draw from house races between the years $2006-2010$.

\section{Methods}

This paper will attempt to answer whether there is an appreciable difference in electoral competition by measuring the election results before and after the introduction of the Citizens' Election Fund. To what extent, if any, has the program increased the level of competition in state house elections and altered the political landscape in Connecticut? To address these questions, this study will analyze data from state house races in the 2006, 2008 and 
2010 election cycles to compare trends in pre and post-reform periods. A database was constructed utilizing data drawn from the Secretary of State's Office and the State Elections Enforcement Commission in Connecticut.

There are a variety of possible metrics to capture electoral competition. This paper will utilize those employed by Mayer, Werner and Williams (2005) which are as follows:

1) The percentage of incumbents who faced a major party opponent (contestedness),

2) the percentage of incumbents who were in a competitive race, defined as one in which the winner received less than $60 \%$ of the two-party vote (competitiveness)

3) the percentage of incumbents who ran and were reelected to office (reelection rate)

\section{Results}

One of the desired outcomes or measures of effectiveness for public campaign financing laws is their purported positive effect on electoral competition. Historically in Connecticut, many house seats go unchallenged due to the incumbency advantage. This has been an increasing trend since the 1980s (McKee 1983) in which Democrats have held a majority of the seats in the General Assembly for all put two of the last thirty years.

A cursory review of the data reveals that one positive effect that public funding seems to have is on the number of uncontested seats in the House and Senate. The number of uncontested seats in the General Assembly declined by $10 \%$ from 2008 to 2010 (Secretary of State, 2010). In the house, 48 out of 151 seats went uncontested as compared to 2008 with 53 going unchallenged. Contestation appears to be greater overall for state senate seats with only 6 out of 36 seats going unchallenged (Secretary of State, 30). However, upon further examination of the data, contestation levels appear to have returned to roughly the same level during the pre-CEF period when 43 out of 151 or $28.5 \%$ of seats went unchallenged.

\begin{tabular}{|ll|}
\hline \multicolumn{2}{|l|}{ State House Races } \\
Year Uncontested by One of the Major Parties Percentage \\
$1998 \quad 43$ out of $15128.5 \%$ \\
$2000 \quad 60$ out of $15140.4 \%$ \\
2002 & 50 out of $15133.1 \%$ \\
2004 & 60 out of $15140.4 \%$ \\
2006 & 62 out of $15141 \%$ \\
2008 & 53 out of $15135 \%$ \\
2010 & 48 out of $15131.8 \%$ \\
\hline
\end{tabular}

Secretary of State, Press Release June 28, 2010

While it may be tempting to attribute increased contestation to the introduction of the Citizens' Election Fund, the data above do not warrant such a conclusion. Candidate emergence is usually affected by several factors one of which may be public funding. As Mayer and Wood note (1995), "challengers consider the overall strategic environment, and not just the question of fundraising, when making the initial decision to run." $(1995,69)$ Other factors that weigh into a candidate's decision are district competitiveness and the experience and background of the challenger.

A more reliable gauge of electoral competition would be the percentage of incumbents who were in a competitive race. It is possible to draw some inferences by examining the percentage of the vote share for each candidate. When both candidates have opted to utilize public funds and thereby establishing a level playing field between candidates, one would expect that the introduction of public funding into a race will erode an incumbent's vote share over time. Effectively, it means that both candidates will have to abide by the same rules and spending limits. On the other hand, others have argued that spending limits institutionalize the incumbents' advantage.

\section{Comparison of 2006, 2008 and 2010 Election Cycles}

During the inaugural run of the Citizens Election Program in 2008 there was no appreciable difference in the percentage of uncontested House races. In fact, uncontested House seats increased slightly between 2006 and 2008 from 40 to 46. From the vantage point of participation in the Citizens' Election Program, the 2008 election cycle was a success with $73 \%$ of General Assembly candidates participating in the program. Incumbents appeared to benefit the most from CEP with $78 \%$ having won reelection utilizing public funds (CEP, 2009). Only six incumbents lost their seats which translated into a five percent increase in the success rate of challengers. 
Table 1. Indicators for voter choice and electoral competition

\begin{tabular}{|c|c|c|c|c|c|c|}
\hline \multirow[t]{2}{*}{ CANDIDATES } & \multicolumn{2}{|c|}{ SENATE } & \multicolumn{2}{|c|}{ HOUSE } & \multicolumn{2}{|c|}{ BOTH CHAMBERS } \\
\hline & 2006 & 2008 & 2006 & 2008 & 2006 & 2008 \\
\hline \multicolumn{7}{|c|}{ Total Candidates and District Races } \\
\hline \multicolumn{7}{|l|}{ Total number of } \\
\hline Total races & 36 & 36 & 151 & 151 & 187 & 187 \\
\hline \multicolumn{7}{|l|}{ Incumbents } \\
\hline Incumbents & 32 & 32 & 139 & 131 & 171 & 163 \\
\hline \multicolumn{7}{|l|}{ Incumbents who } \\
\hline won & 32 & 31 & 133 & 125 & 165 & 156 \\
\hline \multicolumn{7}{|c|}{ Challengers (candidate facing incumbent) } \\
\hline Challengers & 27 & 28 & 116 & 103 & 143 & 131 \\
\hline Challengers who & & & & & & \\
\hline won & 0 & 1 & 6 & 6 & 6 & 7 \\
\hline \multicolumn{7}{|c|}{ Minor party or petitioning candidates } \\
\hline \multicolumn{7}{|l|}{$\begin{array}{l}\text { Minor party or } \\
\text { petitioning }\end{array}$} \\
\hline candidates & 6 & 7 & 39 & 32 & 45 & 39 \\
\hline \multicolumn{7}{|l|}{$\begin{array}{l}\text { Minor party or } \\
\text { petitioning }\end{array}$} \\
\hline \multicolumn{7}{|l|}{ candidates who } \\
\hline won & 0 & 0 & 0 & 0 & 0 & 0 \\
\hline \multicolumn{7}{|l|}{ Uncontested races } \\
\hline Uncontested races & 6 & 7 & 40 & 46 & 46 & 53 \\
\hline \multicolumn{7}{|c|}{ Open seat races (no incumbent running) } \\
\hline Open seat races & 4 & 4 & 12 & 20 & 16 & 24 \\
\hline \multicolumn{7}{|c|}{ Average number of candidates per district } \\
\hline \multicolumn{7}{|l|}{ Average number of } \\
\hline district & 1.92 & 1.94 & 1.86 & 1.81 & 1.89 & 1.88 \\
\hline
\end{tabular}

OLR Research Report, February 9, 2009, State of Connecticut

While incumbents still generally held onto their seats in 2008, the races were closer as seen in the narrowing of the vote margin. In the House, the average vote disparity decreased 33\% in 2006 to $23.26 \%$ in 2008 (SEEC, 2009, p. 27).

\section{State House Elections}


During the second election cycle in $2010,70 \%$ of the total General Assembly candidates participated in the Citizens Election Program, roughly the same amount as in 2008. There was a slight improvement in the prospects of challengers with the vote disparity among competitive house races decreasing from $23 \%$ in 2008 to $18 \%$ in 2010 . A total of 11 incumbents lost their seats in state house. However, it is not clear that the CEP accounted for a greater number of incumbents losing their seats. The strategic environment in 2010 was decidedly different than 2008. The General Assembly elections in Connecticut coincided with midterm elections in Congress. Dissatisfaction with the national economy and the Republican tide that swept many incumbents from office elsewhere may have had a spillover effect in Connecticut.

In order to draw firmer conclusions regarding the efficacy of CEP, further statistical tests will be conducted in order to consider other variables that may account for increased electoral competition such as the overall strategic and electoral environment.

Table 2. Citizens' election program: participation during 2008 election cycle

\begin{tabular}{cccc}
\hline SENATE & HOUSE & BOTH \\
& & & CHAMBERS
\end{tabular}

\section{Total Candidates}

Total number of legislative candidates

Candidates who won (equal to number of districts)

\section{Participating Candidates}

Participating candidates

Participating candidates who received grant*

\section{Participating Incumbents}

Participating incumbents

\section{Participating Challengers}

Participating challengers

Participating challengers who won

Participating Minor Party or Petitioning candidates

Participating minor party or petitioning candidates

Participating minor party or petitioning candidates who received grant*

Participating minor party or petitioning candidates who won

\section{Participating Open Seat Candidates}

Participating open seat candidates

Participating open seat candidates who won 
Several metrics are utilized to capture the relevance of other dimensions of the reach of the elections law specifically the following:

(i) Change in the margin of victory for each particular state house race, both in absolute terms and as a percent of the total vote. It is hypothesized that the increased competition brought about by public funding would reduce the margin of victory as measured by both metrics.

(ii) Electoral races are considered competitive if the incumbent receives less than $60 \%$ of the vote. The electoral law should increase competitiveness.

(iii) Another measure of competitiveness is the total number of votes cast by the opposition. The electoral law should result in an increase in the number of votes cast by the opposition.

(iv) Party diversity is considered a desirable outcome and is measured by the Hirschman-Herfindahl Index of Concentration (HHI) which looks at the share of party presence in the various races and also at the share of total votes garnered by each party. The HHI is a sample statistics and therefore its sampling variance can be calculated. Formally, the index is calculated as follows:

$$
\mathrm{HHI}=1000 * \sum_{i}^{n} s i
$$

Where: $\mathrm{Si}$ is the relevant share of the either party presence or share of votes. The higher the index the less diversity is present. The maximum is $\mathrm{HHI}=10,000$, representing a one party outcome.

The data on the realized value of these other metrics are presented in Table 2.

Table 3.

\begin{tabular}{lccc}
\hline Metric & 2006 & 2008 & 2010 \\
\hline & & & \\
& & & \\
Average Winning Margin of Races (Levels) & 3142 & 4352 & 2297 \\
$\begin{array}{l}\text { Winning Margin of Votes Cast (\% of total } \\
\text { votes cast) }\end{array}$ & $57.5 \%$ & $54.8 \%$ & $41.0 \%$ \\
$\begin{array}{l}\text { Competitive Vote Margin (is the average } \\
\text { outcome less than or equal to 60\%?) }\end{array}$ & $60.0 \%$ & $55.0 \%$ & $71.5 \%$ \\
$\begin{array}{l}\text { Total Number of Votes Cast by Opposition } \\
\text { Diversity Index of Opposition (Herfindahl on }\end{array}$ & 233,864 & 361,352 & 367,999 \\
$\begin{array}{l}\text { Share of Party Presence in the Various Races) } \\
\text { Diversity Index of Opposition (Herfindahl on }\end{array}$ & 5588 & 3562 & 3995 \\
\begin{tabular}{l} 
Share of Votes Garnered by Party) \\
\hline
\end{tabular} & 5844 & 5402 & 5849 \\
\hline
\end{tabular}

Table one demonstrates that the average winning margins decreased in 2010 over the two previous elections in $41 \%$ of state house races. However, in those races where incumbents won, they were much less competitive overall with incumbents garnering $71.5 \%$ of the vote.

\section{Results: Additional Metrics}

Procedurally the same method is used gain with the addition of permutation methods to test the hypothesis and to generate p-values. The results are presented in Table 2.

Few of the metrics exhibit statistically significant change between the 2006 and 2008 election cycle. Thus, the observed improvement in the winning margin of votes cast as a percent of total votes cast is not statistically significant. The same findings emerge for the two diversity indexes estimated. Second, there is discernible change in the metrics between 2006 and 2008 that is contrary to what one would expect - but the change is not statistically 
significant. For example, there is an increase in the average winning margin (levels) of votes between 2006 and 2008 (from 3142 votes to 4352 ) rather than the anticipated decrease.

Table 4.

\begin{tabular}{|c|c|c|}
\hline Metric & 2006-08 & 2006-10 \\
\hline $\begin{array}{l}\text { Change in the Average Winning } \\
\text { Margin of Voters }\end{array}$ & 1,209 & $(845)$ \\
\hline p-value & $(0.561)$ & $(0.487)$ \\
\hline $\begin{array}{l}\text { Difference in the Winning Margin of } \\
\text { Votes Cast ( } \% \text { of total votes cast) }\end{array}$ & $(0.03)$ & $(0.17)$ \\
\hline p-value & $(0.657)$ & $(0.0417) *$ \\
\hline $\begin{array}{l}\text { Difference in the Competitive Vote } \\
\text { Margin (is the average outcome less } \\
\text { than or equal to } 60 \% \text { ) }\end{array}$ & $(0.05)$ & 0.12 \\
\hline p-value & $(0.053)$ & $(0.0017)^{*}$ \\
\hline $\begin{array}{l}\text { Change in the Total Number of } \\
\text { Votes Cast by Opposition }\end{array}$ & 127,488 & 134,135 \\
\hline p-value & $(0.031) *$ & $(0.0432) *$ \\
\hline $\begin{array}{l}\text { Change in the Diversity Index of } \\
\text { Opposition (Herfindahl on Share of } \\
\text { Party Presence in the Various Races) }\end{array}$ & (27) & 407 \\
\hline p-value & $(0.671)$ & $(0.450)$ \\
\hline $\begin{array}{l}\text { Change in the Diversity Index of } \\
\text { Opposition (Herfindahl on Share of } \\
\text { Votes Garnered by Party) }\end{array}$ & $(442)$ & 5 \\
\hline$p$-value & $(0.759)$ & $(0.562)$ \\
\hline
\end{tabular}

There are more significant changes in the comparison with the 2010 election cycle. But the results are contradictory. Positive improvements in the winning margin of votes cast are found but also a deterioration of competitive vote margin. Incumbents continue to win with larger margins. Both are statistically significant. Importantly, the party diversity indexes show no statistically discernible improvement at all, whether from the comparison to the 2008 or the 2010 cycle. A somewhat troubling indicator is the fact that party and opposition diversity appears to have deteriorated by 2010 when compared to the party and opposition layout present in the 2006 election, although the difference is not statistically meaningful.

\section{Discussion}

The results examining the impact of the Citizens' Election Program on electoral competition are mixed: some metrics do suggest statistically meaningful differences whereas many others do not. Hardly any statistically significant results are evident in the 2008 cycle. With token exceptions, all of the minute differences observed, when they are in fact observed, occur by the 2010 election cycle.

Ironically, a law aiming to enhance electoral competition strengthened the position of the Democrats in a robustly blue state: the results of several metrics appear to have given a slight edge to Democrats, at the expense of Republicans. Given the variance in the information provided by the assembled metrics it is difficult to conclude whether the public funding of elections in the State of Connecticut is an unqualified success, or for that matter, a qualified success. First, no one metric takes precedence over another. Second, any weighted combination of metrics must necessarily rely on subjective weights. Third, performance is essentially multidimensional: superior performance against one objective cannot easily be traded off against modest or inadequate performance on 
another. Fourth, several of the proposed 'success' criteria may be specified inadequately. Fifth, and at any rate, 'success' in this instance refers to the performance of the chosen metrics. Put differently, the examination scrutinized instruments, not final outcomes.

It should be clear that the lack of conclusive discernible effects is not evidence against the benefits of the Connecticut clean election law. The result may also be a consequence of low statistical power or that the existing law left several gaping loopholes. In fact, one could realistically argue that because of remaining porosity in the system the current law may not sufficiently curtail the privately-directed flow of funds to favored candidates. And given the presence of Citizens United it is not clear whether there can be any further tightening. Last, given the historical importance of local town and municipal elections in Connecticut a law aimed at alleviating the ills of the state electoral system may miss the well known point that all elections are local and that funding municipal elections may be as important to fostering electoral competition.

Thus, no conclusions can be drawn regarding the efficacy of the law. It appears that with respect to the trial run of the Citizens' Election Program, the jury is still out. Further research which is inclusive of more elections will have to be conducted before any one conclusion can be unambiguously drawn or the effusiveness and optimism of the various commentators supporting clean election laws can be fully substantiated. More time is needed to declare a victory for clean elections in Connecticut.

\section{References}

Brickner, B. T., \& Mueller, N. (2008). Clean Elections Public Financing in Six States including New Jersey's Pilot Projects. New Jersey: Eagleton Institute of Politics, Rutgers University.

Citizen Clean Elections Commission. (2010). Participating Candidates Guide 2010 Election Cycle. Retrieved from http://www.azcleanelections.gov/forms-pubs/2009-2010/candidates/participating.aspx

Connecticut General Assembly, Proceedings, House of Representatives. (November 30, 2005).

Donnay, P. D., \& Graham P. R. (1995). Public Financing of Legislative Elections: Lessons from Minnesota. Legislative Studies Quarterly, 20(3), 351-364. http://dx.doi.org/10.2307/440225

Fahle, H. W. (2009). Slanting the Playing Field Connecticut's Flawed Publicly Funded Campaign System. The Yankee Institute for Public Policy.

Lockard, D. (1959). New England State Politics. Princeton: Princeton University Press.

Mayer, K. (2007). Electoral Transitions in Connecticut: The Implementation of Clean Elections in 2008 (selected works).

Mayer, K. R., Werner T., \& Williams, A. (2005). Do Public Funding Programs Enhance Electoral Competition? Paper presented at the Fourth Annual Conference on State Politics and Policy Laboratories of Democracy: Public Policy in the American States, Kent State University, April 30-May 1, 2004.

McKee, C. D. (1983). Connecticut: A Political System in Transition. In J. F. Millburn, \& W. Doyle (Eds.), New England Political Parties. Cambridge: Schenkman Publishing Co.

Nyart, N. (2006). A Consensus for Reform: Connecticut Lawmakers Opt for Public Financing. National Civic Review. http://dx.doi.org/10.1002/ncr.133

Rose, G. L. (2007). How Blue is Connecticut. In Connecticut Government and Politics An Introduction. Sacred Heart University Press.

State Elections Enforcement Commission. (2011, January). Citizens Election Program 2010 A Novel System with Extraordinary Results.

State Elections Enforcement Commission. (2009, October). Connecticut - Reclaiming Democracy The Inaugural Run of the Citizens' Election Program for the 2008 Elections'.

Sullivan, K. (2009, February). The Citizens Election Program: A Comparison of the 2006 Legislative Races with the 2008 races. OLR Research Report, State of Connecticut.

Werner, T., \& Mayer, K. R. (2007). Public Election Funding, Competition, and Candidate Gender. Retrieved from http://www.aspanet.org 


\section{Notes}

Note 1. Public grants in some states have been in existence since the 1970's however the size of the grants were relatively small and often combined with other sources of private funding. The term clean elections is widely considered to have received its inauguration with the inception of the public funding program in Arizona which has been heralded as a model for other states.

Note 2. Mayer and Williams (2007) used the term "sclerotic" to describe the nature of Connecticut's electoral system. The term has been amply applied in other areas of political science to describe inertia in certain political processes.

\section{Copyrights}

Copyright for this article is retained by the author(s), with first publication rights granted to the journal.

This is an open-access article distributed under the terms and conditions of the Creative Commons Attribution license (http://creativecommons.org/licenses/by/3.0/). 